\title{
POESIA COLOMBIANA CONTEMPORÂNEA: POEMAS DE ORIETTA LOZANO TRADUZIDOS
}

\author{
CONTEMPORARY COLOMBIAN POETRY: POEMS BY ORIETTA LOZANO \\ TRANSLATED
}

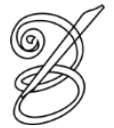 \\ Traduzido por: \\ Mariana Cristina Pinto MARINO* \\ Universidade Federal do Paraná \\ Curitiba, Paraná, Brasil
}

Resumo: Orietta Lozano nasceu em Cali, Colômbia, em 1956, onde reside até hoje. É poeta, ensaísta e novelista e apresenta uma produção poética expressiva iniciada na década de 1980. No entanto, mesmo tendo composto diversas antologias nacionais e internacionais, sendo uma delas brasileira, organizada pela poeta Lucila Nogueira e por Floriano Martins em 2007, a obra de Lozano ainda é pouquíssimo difundida no Brasil, sendo mais conhecida na Colômbia e no México, apesar de haver traduções de poemas também para o inglês, o francês e o italiano. Os poemas aqui apresentados e traduzidos, Danza e Despojada, integram a segunda publicação da autora, Memoria de los Espejos, de 1983, e podem ser considerados bons representantes da poética de Orietta Lozano, pois revelam imagens que evocam uma força sensitiva dos elementos, uma linguagem repleta de um desejo transgressor fundamentado num tempo mítico, num jogo místico.

Palavras-chave: Tradução. Poesia colombiana. Orietta Lozano.

Abstract: Orietta Lozano was born in Cali, Colombia, in 1956, where she lives today. She is a poet, essayist and novelist and presents an expressive poetic production that began in the 1980s. However, despite having composed several national and international anthologies, one of them being Brazilian, organized by the poet Lucila Nogueira and Floriano Martins (2007), the work de Lozano is still very little widespread in Brazil, being best known in Colombia and Mexico, although there are translations of poems also into English, French and Italian. The poems presented and translated here, "Danza" and "Despojada", make up the author's second publication, "Memoria de los Espejos", from 1983, and can be considered good representatives of Orietta Lozano's poetics, as they reveal images that evoke a sensitive force of the elements, a language full of a transgressive desire based on a mythical time, a mystical game.

Keywords: Translation. Colombian poetry. Orietta Lozano.

RECEBIDO EM: 21 de outubro 2019

ACEITO EM: 26 de fevereiro 2020

PUBLICADO EM: março 2020

MARINO, Mariana. Poesia colombiana contemporânea: poemas de Orietta Lozano traduzidos. Belas Infiéis, Brasília, v. 9, n. 2, p. 305-308, 2020. 
egundo Orietta Lozano" "la poesía es una orden, una profecía, un edicto" (2015). Não à toa, a autora colombiana, nascida em Cali, em 1956, leva essa quase devoção pela poesia bastante a sério. Tendo publicado mais de dez livros desde 1980, em sua maioria de poemas, participado de antologias no México, no Brasil e em Portugal, e sido traduzida em inglês, francês e italiano, Lozano ainda tem para a conta uma vasta experiência como diretora e coordenadora de bibliotecas (como a Biblioteca Municipal del Centenario, primeira biblioteca pública de Cali) e como organizadora de eventos e festivais culturais em Cali. Em 1986, El vampiro esperado, seu terceiro livro de poemas, é agraciado com o Prêmio Nacional de Poesia Eduardo Cote Lamus; em 1993, Lozano recebe o prêmio de Melhor Verso Erótico, promovido pela Casa de Poesía Silva, uma organização cultural e histórica da Colômbia, localizada em Bogotá.

Além disso, a poeta colombiana já foi convidada a participar de festivais literários e poéticos na América Latina e na Europa: em 1995, vai à França para a XIII Bienal Internacional de Poetas; participa do $27^{\circ}$ Festival Internacional de Poesia de Medellin, em 2017; ministra formações sobre arte e cultura pela Secretaria de Valle del Cauca (região da 306 Colômbia que abarca Cali e outros 40 municípios), em 2019.

No Brasil, Orietta Lozano integra a antologia Mundo Mágico: Colômbia- Poesia Colombiana do século XX (2007), organizada pela poeta Lucila Nogueira e por Floriano Martins. Apesar da seleção e tradução de poemas de Lozano, a autora ainda não consegue atingir uma expressividade considerável no país. Em Portugal, a autora integra a obra Um país que sonha (Cem anos de poesia colombiana), primeira antologia de poesia colombiana publicada no país, em 2012, organizada por Lauren Mendinueta, com tradução do poeta português Nuno Júdice.

Em La herida de los siglos, publicado em 2015, escritores, tradutores e jornalistas (colombianos e latino-americanos) escrevem pequenas notas sobre a poesia de Lozano, como que em uma edição comemorativa. Evocamos aqui algumas palavras de Eduardo Espina. escritor uruguaio, que assegura perceber, na obra da colombiana, "o silêncio, a obscuridade, o caos, o próprio ato de escrever, o amor, a solidão, a memória e o sonho”. Para além desses elementos, realmente passíveis de serem encontrados ao longo da obra de Lozano, há que se notar também, como ainda pontua Espina, a existência de um tempo mítico que associa esses elementos, geralmente atrelados a uma devoção regida pelos fundamentos da natureza. Em Danza e Despojada, ambos pertencentes à segunda obra da autora colombiana, Memoria de los espejos (1983), essas percepções podem ser identificadas. Como alguém que está 
intrinsecamente ligada à história da América Latina, seus desdobramentos e conexões com a terra, os poemas de Orietta Lozano nos conectam a esse tempo outro, em que a obscuridade e o silêncio são um acalento, não um sinal de perigo.

\section{Danza}

¿Qué voz hace crujir el vestido de seda de esta noche, y entreabrir los muslos tiernamente y desnudar su espalda de mujer? Parece ser el canto ebrio de bacantes, el susurro lejano y negro de una viuda o la lluvia entrecortada de una novia. ¿Qué voz extraña hace que el viento se levante y dance, y la luna galope en el lomo de un caballo, y el lago abra su ojo cristalino más que nunca? Levántate amor. La noche espera ser ungida, sacrificada como una diosa frágil entre los brazos de la tierra.

\section{Despojada}

Dónde despertar, en qué momento, lo inmediato duele, quema, explota bruscamente entre mis cejas. La búsqueda se ha perdido, el tiempo cayó goteando por tus ojos todo crimen quedó estático en mis sienes,

yo me hundo en cada flor como la abeja y ningún fruto se perfila.

Me he despojado de todo encuentro, sobre mi hombro se posa el pájaro del silencio y a veces, sólo a veces, la carcajada del delirio viene a perforar los huesos a mi hastío.

\section{Dança}

Que voz faz crepitar o vestido de seda desta noite, e entreabrir as coxas ternamente e desnudar suas costas de mulher? Parece ser o canto ébrio das bacantes, o sussurro longínquo e negro de uma viúva ou a chuva entrecortada de uma noiva. Que voz estranha faz com que o vento se levante e dance, e a lua galope no lombo de um cavalo, e o lago abra seu olho cristalino mais que nunca? Levanta, amor. A noite espera ser ungida, sacrificada como uma deusa frágil entre os braços da terra.

\section{Despojada}

Onde despertar, em que momento, o imediato dói, queima, explode bruscamente em minhas sobrancelhas. A busca foi perdida, o tempo caiu gotejando por seus olhos todo crime permaneceu estático em minhas têmporas ${ }^{2}$, eu me afundo em cada flor como a abelha e nenhum fruto se perfila.

Me despojei de todo encontro, sobre meu ombro pousa o pássaro do silêncio e às vezes, só às vezes, a gargalhada do delírio vem perfurar os ossos para o meu desgosto. 


\section{REFERÊNCIAS}

EL ESPECTADOR. Escribo para ver el resplandor: Orietta Lozano. 2015. Disponível em: https://www.elespectador.com/noticias/cultura/escribo-ver-el-resplandor-orietta-lozanoarticulo-580560 Acesso em: 15 fev. 2020.

LOZANO, Orietta. Memoria de los espejos. Bogotá: Ediciones Puesto de Combate, 1983.

LOZANO, Orietta. La herida de los siglos. Bogotá: Uniediciones, 2015.

MARTINS, Floriano; NOGUEIRA, Lucila. Mundo Mágico: Colômbia- Poesia Colombiana do século XX. Recife: Editora Bagaço, 2007.

MENDINUETA, Lauren (org.). Um país que sonha: Cem anos de poesia colombiana. Lisboa: Assírio e Alvim, 2012.

\footnotetext{
* Mariana Cristina Pinto MARINO - Licenciada em Letras - Português e Inglês (2014) pela Universidade Tecnológica Federal do Paraná e mestra em Estudos de Linguagens (2018) pela mesma instituição. Dutoranda em Letras na Universidade Federal do Paraná, bolsista pela Agência CAPES/PROEX. Universidade Federal do Paraná, Setor de Ciência Humanas, Programa de Pós-Graduação em Letras. Curitiba, Paraná, Brasil.

Currículo acadêmico: http://lattes.cnpq.br/9963891903410804

ORCID: https://orcid.org/0000-0002-3558-8305

308 E-mail: mariana.cmarino@gmail.com

${ }^{1}$ Orietta Lozano autorizou a tradução e publicação dos poemas traduzidos em 23 de outubro de 2019 via e-mail à tradutora.

${ }^{2}$ Em razão da diagramação, há uma quebra de verso que não deveria ocorrer.
} 